The London bombings

\section{Injury prevention and terrorism}

\section{B Pless}

\section{The late Robin Cook recognised the association between poverty and terrorism}

a am simply not smart enough to be able to add anything sensible or profound to what so many others have written on this topic. After 9/11 I offered some thoughts on the immense challenge that preventing terrorist acts entails. ${ }^{1}$ No one wrote to agree or disagree so I concluded that either my suggestions were too controversial or too mundane. On this occasion, roughly one month after the London bombings at the time of writing, I feel obliged to try again. I do so because a journal dedicated to preventing the consequences of injuries cannot ignore terrorism. I also do so because it comes so close to home. The London bombings took place a week after we left following a brief visit for a family emergency. Ordinarily we would have stayed on and spent some time in London, quite possibly in the areas where the bombings occurred. Certainly I would have visited the Injury Prevention journal editorial office at BMA house and may well have gone there on a number 30 bus.

But what is there left to say? I have read so many diverse opinions about how future attacks can be prevented, ranging from all out warfare to accepting their inevitability. Somehow the answer, such as it is, must lie somewhere between these extremes. The view that appeals most to me and that I want to share with our readers is that expressed by the late Robin Cook, a UK Labour MP and former foreign secretary, who died recently while hill walking in Scotland. ${ }^{2}$ On July 8 , the day after the London bombings, he wrote the following in the Guardian newspaper: "In the absence of anyone else owning up to yesterday's crimes, we will be subjected to a spate of articles analysing the threat of militant Islam. Ironically they will fall in the same week that we recall the tenth anniversary of the massacre at Srebrenica, when the powerful nations of Europe failed to

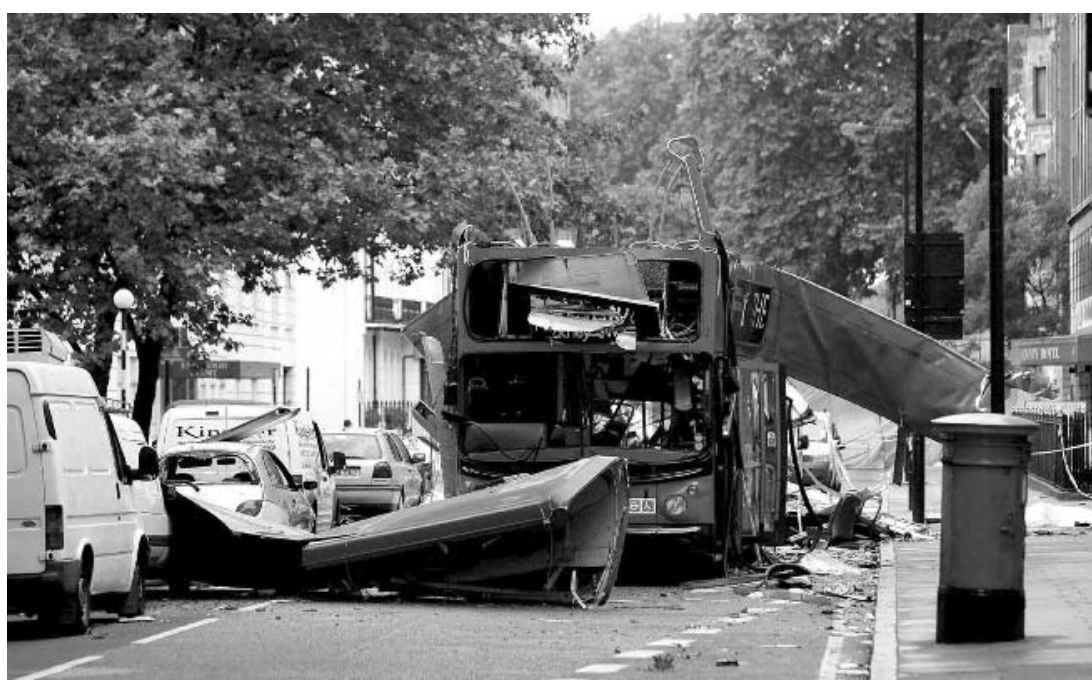

Fourteen people (including the bomber) died on the number 30 bus shown. The explosion took place near the entrance to BMA House (just out of picture) where the Injury Prevention journal offices are located. $\odot$ Rex Features. protect 8,000 Muslims from being annihilated in the worst terrorist act in Europe of the past generation." Cook goes on to say, "So long as the struggle against terrorism is conceived as a war that can be won by military means, it is doomed to fail. The more the west emphasises confrontation, the more it silences moderate voices in the Muslim world who want to speak up for cooperation. Success will only come from isolating the terrorists and denying them support, funds and recruits, which means focusing more on our common ground with the Muslim world than on what divides us." Cook suggests that "it would be perverse if the focus of the G8 on making poverty history was now obscured by yesterday's bombings. The breeding grounds of terrorism are to be found in the poverty of back streets, where fundamentalism offers a false, easy sense of pride and identity to young men who feel denied of any hope or any economic opportunity for themselves. A war on world poverty may well do more for the security of the west than a war on terror. And in the privacy of their extensive suites, yesterday's atrocities should prompt heart-searching among some of those present. President Bush is given to justifying the invasion of Iraq on the grounds that by fighting terrorism abroad, it protects the west from having to fight terrorists at home. Whatever else can be said in defence of the war in Iraq today, it cannot be claimed that it has protected us from terrorism on our soil."

There is much more that I could write on this topic but Cook's views capture the essence of what I believe. If we are truly committed to prevention at the most fundamental level, we cannot focus only on proximal measures; at some point, the root causes also must be addressed. No one familiar with the injury prevention literature should be surprised to learn that, once again, there is an underlying powerful association with poverty. Literally, we ignore that association at our peril.

Injury Prevention 2005;11:257.

doi: 10.1136/ip.2005.010116

Correspondence to: Professor I B Pless, Editor; barry.pless@mcgill.ca

\section{REFERENCES}

1 Pless B. Preventing terrorist attacks. Inj Prev Dec 2001;7:257

2 Cook R. The Guardian, 8 July 2005 